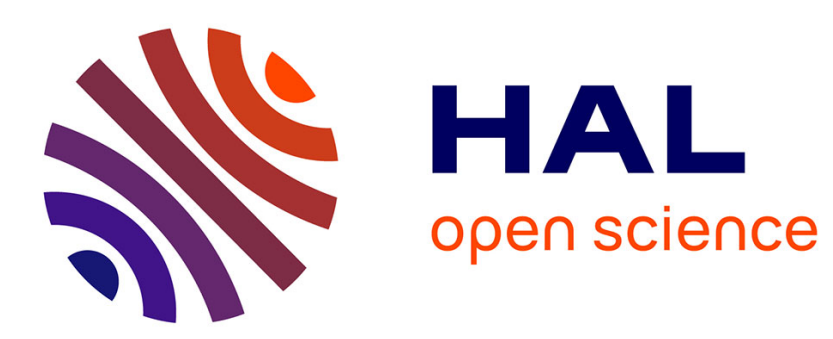

\title{
Isolation and characterization of microsatellite loci for the European tree frog (Hyla arborea)
}

\author{
L. Berset-Brändli, Julie Jaquiéry, T. Broquet, N. Perrin
}

\section{To cite this version:}

L. Berset-Brändli, Julie Jaquiéry, T. Broquet, N. Perrin. Isolation and characterization of microsatellite loci for the European tree frog (Hyla arborea). Molecular Ecology Resources, 2008, 8 (5), pp.10951097. 10.1111/j.1755-0998.2008.02189.x . hal-02655760

\section{HAL Id: hal-02655760 \\ https://hal.inrae.fr/hal-02655760}

Submitted on 29 May 2020

HAL is a multi-disciplinary open access archive for the deposit and dissemination of scientific research documents, whether they are published or not. The documents may come from teaching and research institutions in France or abroad, or from public or private research centers.
L'archive ouverte pluridisciplinaire HAL, est destinée au dépôt et à la diffusion de documents scientifiques de niveau recherche, publiés ou non, émanant des établissements d'enseignement et de recherche français ou étrangers, des laboratoires publics ou privés. 


\title{
PERMANENT GENETIC RESOURCES Isolation and characterization of microsatellite loci for the European tree frog (Hyla arborea)
}

\author{
L. BERSET-BRÄNDLI, J. JAQUIÉRY, T. BROQUET and N. PERRIN \\ Department of Ecology and Evolution University of Lausanne, CH 1015 Lausanne, Switzerland
}

\begin{abstract}
We developed 11 new microsatellite markers for the European tree frog (Hyla arborea), and tested patterns of polymorphism in 54 adults $(27$ males and 27 females) from two ponds close to Lausanne (Western Switzerland). One marker was sex linked and two pairs displayed linkage disequilibrium. Comparisons of allele numbers with heterozygosity values support a stepwise-mutation model at neutral equilibrium, with mutation rates spanning nearly two orders of magnitude. These markers will prove useful for population genetic studies and fine-scale investigations requiring genetic assignment techniques.
\end{abstract}

Keywords: European tree frog, Hyla arborea, microsatellites, stepwise-mutation model

Received 25 November 2007; revision accepted 29 January 2008

The European tree frog (Hyla arborea) is widespread throughout Europe, from the coasts of the Atlantic Ocean to the shores of the Black Sea. Like many amphibians, this species has recently declined over its range, mostly due to anthropogenic landscape changes. A series of 15 microsatellite markers developed by Arens et al. (2000) have been used to document the effects of fragmentation on genetic variance, and estimate connectivity among residual populations from Denmark (Andersen et al. 2004) and the Netherlands (Arens et al. 2006). However, some of these markers later appeared to be sex linked (Ha5-22, Ha1-60 and Ha5-201; Berset-Brändli et al. 2006, 2007), difficult to amplify or score (Ha1-104, Ha1-140), or to display null alleles (Ha1-9) or insufficient polymorphism for investigations on Swiss populations (L. Berset-Brändli, J. Jaquiéry, T. Broquet, N. Perrin, unpublished results). We thus set out to characterize new markers for this species.

Specific markers were developed from genetic libraries enriched for microsatellite motifs constructed by Genetic Identification Services (GIS, www.genetic-id-services.com). Libraries were built using a pooled sample containing $100 \mu \mathrm{g}$ of genomic DNA extracted from 10 tadpoles collected in Western Switzerland. Libraries were enriched for CA, GA, CAG, AAC, AAT, TAGA, CATC and TACA following Jones et al. (2002). Out of 63 different microsatellite-

Correspondence: N. Perrin, Fax: 00412169241 65; e-mail: nicolas.perrin@unil.ch containing clones, 39 had flanking sequences of length sufficient for primer design using DESIGNERPCR version 1.03 (Research Genetics, Inc.). Of 39 pairs of primers tested, 11 pairs amplified microsatellites that were both easy to score and polymorphic enough to be potentially useful for population genetic analyses.

These microsatellites were amplified in $20-\mu \mathrm{L}$ reaction volumes each containing $0.2 \mathrm{~mm}$ dNTP, $0.5 \mu \mathrm{M}$ of each primer, $1 \times$ QIAGEN PCR buffer (with $\mathrm{MgCl}_{2} 15 \mathrm{~mm}$ ), $0.2 \mathrm{~mm}$ $\mathrm{MgCl}_{2}$ (no $\mathrm{MgCl}_{2}$ for Ha-H108, Ha-E2 and Ha-D115), $1 \mathrm{U}$ QIAGEN Taq and $1 \mu \mathrm{L}$ of extracted DNA. The polymerase chain reaction (PCR) programmes were performed on GeneAmp PCR Systems 2700 and 9700 (PerkinElmer), according to the following thermal profiles: initial denaturation at $94{ }^{\circ} \mathrm{C}$ for $5 \mathrm{~min}$, followed by 40 cycles at $94{ }^{\circ} \mathrm{C}$ for $45 \mathrm{~s}$, annealing at optimal primer temperature (Table 1) for $45 \mathrm{~s}$, elongation at $72{ }^{\circ} \mathrm{C}$ for $1 \mathrm{~min}$, and a final elongation step at $72{ }^{\circ} \mathrm{C}$ for $5 \mathrm{~min}$. Amplification products were run on an ABI PRISM 3100 (Applied Biosystems) automated DNA sequencer. Alleles were scored with GENEMAPPER 3.7 (Applied Biosystems).

The markers were tested on 54 adults ( 27 males and 27 females) from two ponds close to Lausanne (Switzerland). Individuals were sampled with two buccal swabs each (Broquet et al. 2007), then released at the place of capture. Buccal swabs were stored dry at $-80^{\circ} \mathrm{C}$ before analysis. DNA was extracted using a QIAGEN DNeasy Tissue Kit following the manufacturer's protocol, except that samples were incubated overnight at $56{ }^{\circ} \mathrm{C}$ in proteinase $\mathrm{K}$. After 
Table 1 Characterization of 11 polymorphic microsatellite loci for the European tree frog Hyla arborea. \{Reported are: locus name; repeat motif, sequences for forward $(\mathrm{F})$ and reverse $(\mathrm{R})$ primers; optimal annealing temperature $\left(T_{\mathrm{a}}\right)$; allele size range in base pairs; number of alleles $(k)$; observed $\left(H_{\mathrm{O}}\right)$ and expected $\left(H_{\mathrm{E}}\right)$ heterozygosity calculated on 54 adults (27 males and 27 females); expected number of alleles $\left[E(k)_{\text {SSM }}\right]$ and diversity value $\left(\theta_{\text {SSM }}\right)$ under simple stepwise-mutation model; and GenBank Accession no.\}

\begin{tabular}{|c|c|c|c|c|c|c|c|c|c|c|}
\hline Locus & Repeat motif & Primer sequence $\left(5^{\prime}->3^{\prime}\right)$ & $T_{\mathrm{a}}\left({ }^{\circ} \mathrm{C}\right)$ & $\begin{array}{l}\text { Size range } \\
\text { (bp) }\end{array}$ & $k$ & $H_{\mathrm{O}}$ & $H_{\mathrm{E}}$ & $E(k)_{\text {SSM }}$ & $\theta_{\text {SSM }}$ & Accession no. \\
\hline Ha-A11 & $(\mathrm{CA})_{14}$ & $\begin{array}{l}\text { F: NED-CCTCCCTCACTCTGCTGAC } \\
\text { R: CAATCCCCGAAAAACATTG }\end{array}$ & 58 & $133-145$ & 3 & 0.34 & 0.38 & 2.91 & 0.80 & EU029094 \\
\hline На-А119 & $\begin{array}{l}(\mathrm{CT})_{5}(\mathrm{CA})_{6} \mathrm{TA} \\
(\mathrm{CA})_{14}\end{array}$ & $\begin{array}{l}\text { F: NED-CAACTTCCCCCTCTGTTC } \\
\text { R: GCTGAGTGTGAGTGTGTTTG }\end{array}$ & 58 & $238-250$ & 3 & 0.488 & 0.503 & 3.59 & 1.52 & EU029095 \\
\hline Ha-A127 & $(\mathrm{TG})_{14}$ & $\begin{array}{l}\text { F: HEX-CTCTGGGTTGCACTACTTAGTC } \\
\text { R: TTCAGGGCTAATTCTTTGTATG }\end{array}$ & 56.8 & $277-284$ & 3 & 0.375 & 0.392 & 2.97 & 0.85 & EU029096 \\
\hline Ha-A130 & $(\mathrm{CA})_{10} \ldots(\mathrm{CA})_{13}$ & $\begin{array}{l}\text { F: FAM-ATTGCTCACACATACACACAGG } \\
\text { R: GCAGTCACAACTCATTTTGATG }\end{array}$ & 56.8 & $109-148$ & 5 & 0.442 & 0.482 & 3.46 & 1.36 & EU029097 \\
\hline Ha-B5R3 & $(\mathrm{TC})_{13}$ & $\begin{array}{l}\text { F: FAM-CCCCTTTAGAGTCGCCATAC } \\
\text { R: AGCCATCTTGTGGTCAGTCA }\end{array}$ & 56.8 & $235-245$ & 5 & 0.652 & 0.761 & 6.09 & 8.25 & EU029098 \\
\hline Ha-B12 & $(\mathrm{TC})_{21}$ & $\begin{array}{l}\text { F: HEX-AATGGTATCTCGGTGGTATCC } \\
\text { R: TTGAAAAATCTCTCCCTACAGC }\end{array}$ & 56.8 & $100-118$ & 7 & 0.721 & 0.738 & 5.70 & 6.78 & EU029099 \\
\hline Ha-D3R3 & $(\mathrm{TATC})_{21}$ & $\begin{array}{l}\text { F: NED-ATCACCATCCCTGCATTAC } \\
\text { R: CGACATGATAGATGTGAGATAA }\end{array}$ & 56.8 & $157-169$ & 3 & 0.242 & 0.283 & 2.43 & 0.47 & EU029100 \\
\hline Ha-D115 & $(\mathrm{TAGA})_{16}$ & $\begin{array}{l}\text { F: FAM-GTTTTTCGATTCCTGGATAAC } \\
\text { R: TGGGAGTTTTCAAAAGTGAC }\end{array}$ & 56.8 & $192-216$ & 7 & 0.835 & 0.827 & 7.72 & 16.21 & EU029104 \\
\hline Ha-E2 & $(\mathrm{CAA})_{7}$ & $\begin{array}{l}\text { F: HEX-ACAACTTCCAACTGGAGTCAAC } \\
\text { R: CCTTAGTGGGAGCTGTAATCAC }\end{array}$ & 56.8 & 151-159 & 2 & 0.13 & 0.154 & 1.79 & 0.20 & EU029103 \\
\hline Нa-H107 & $(\mathrm{GT})_{7} \ldots(\mathrm{TATG})_{4}$ & $\begin{array}{l}\text { F: FAM-CACCCTGGTAGGGAAATTC } \\
\text { R: GGCAAATGGGGATGAGTA }\end{array}$ & 56.8 & $267-269$ & 2 & 0.405 & 0.368 & 2.85 & 0.75 & EU029101 \\
\hline На-H108 & $(\mathrm{TACA})_{10}$ & $\begin{array}{l}\text { F: FAM-GGGGGTGAGTAAGGGTTAAATC } \\
\text { R: GCCACTGTATAGTCCCTCCCTA }\end{array}$ & 56.8 & $250-252$ & 2 & 0.5 & 0.377 & 2.90 & 0.79 & EU029102 \\
\hline
\end{tabular}

incubation, a QIA Shredder was used according to the manufacturer's conditions. DNA was eluted in a $200-\mu \mathrm{L}$ volume (QIAGEN Buffer AE), and stored at $-18^{\circ} \mathrm{C}$.

Allele numbers $(k)$ ranged from two to seven, observed heterozygosities $\left(H_{\mathrm{O}}\right)$ from 0.13 to 0.84 , and expected heterozygosities $\left(H_{\mathrm{E}}\right)$ from 0.15 to 0.83 (Table 1 ). We found no significant deviation from Hardy-Weinberg equilibrium after Bonferroni corrections (Goudet 1995) and no evidence for null alleles (MICRO-CHECKER 2.2.3; van Oosterhout et al. 2004). Two pairs of loci (Ha-D115/Ha-A127 and Ha-A119/ Ha-A130) showed significant linkage disequilibrium after Bonferroni corrections (Goudet et al. 1996). One marker (Ha-H108) was sex linked: all females were homozygous for allele 250, and all males heterozygous for alleles 250 and 252 , pointing to a location on the nonrecombining segment of the sex chromosomes.

Diversity values were calculated at each locus assuming either an infinite allele model $\left(\theta_{\text {IAM }}=\mathrm{H}_{\mathrm{E}} / 1-\mathrm{H}_{\mathrm{E}}\right)$ or a onestep stepwise-mutation model $\left[\theta_{\mathrm{SSM}}=1 / 2\left[1 /\left(1-\mathrm{H}_{\mathrm{E}}\right)^{2}-1\right]\right.$ Kimura \& Ohta 1975]. These values ranged from 0.18 to 4.75 for $\theta_{\mathrm{IAM}}$, and from 0.20 to 16.21 for $\theta_{\mathrm{SSM}}$. The number of alleles expected at neutral equilibrium $[E(k)]$ directly relates to this diversity parameter. Under infinite allele model (IAM), $E(k)=\sum_{i=0}^{N-1} \theta /(\theta+i)$ where $N$ is the number of gene copies sampled, while under SSM, $E(k)=(\theta+\beta) / \beta\left[1-\prod_{i=0}^{N-1}(\theta+i) /(\theta+\beta+i)\right]$ where $\beta=\theta(1-$ $\left.H_{\mathrm{E}}\right) / H_{\mathrm{E}}-1$ (Kimura \& Ohta 1975). The regression coefficient of $E(k)_{\text {SSM }}$ vs. $k$ ( $b=0.98$, intercept set to 0$)$ was very close to unity and not significantly different from it $[95 \% \mathrm{CI}(0.85$; 1.13)], with $76 \%$ of the variance explained. By contrast, $E(k)_{\text {IAM }}$, consistently overestimated the number of alleles $[b=1.71,95 \%$ CI $(1.28 ; 2.04)$, intercept set to 0$]$. We conclude that the mutation model does not differ significantly from SSM, and that the population investigated is at neutral equilibrium.

At this equilibrium, the diversity $\theta$ should equal the product of effective size $N_{e}$, mutation rate and gene copy number per mating pair (i.e. $\theta=4 N_{e} \mu$ for autosomal loci). Hence, the ratios of $\theta$ values among loci measure the ratios of their mutation rates. From the ratios of $\theta_{\mathrm{SSM}}$, the mutation rates span nearly two orders of magnitude, being 80 times larger for Ha-D115 than for Ha-E2.

We conclude that the range of diversity values and allele numbers documented for these 11 loci make them suitable tools for population genetic studies, and will also prove useful for investigations on fine-scale dispersal patterns as well as on the mating system of this lek-breeding species. 


\section{References}

Andersen LW, Fog K, Damgaard C (2004) Habitat fragmentation causes bottlenecks and inbreeding in the European tree frog (Hyla arborea). Proceedings of the Royal Society B: Biological Sciences, 271, 1293-1302.

Arens P, Van't Westende W, Butger R, Smulders MJM, Vosman B (2000) Microsatellite markers for the European tree frog Hyla arborea. Molecular Ecology, 9, 1919-1952.

Arens P, Bugter R, Van't Westende W, et al. (2006) Microsatellite variation and population structure of a recovering tree frog ( $\mathrm{Hyla}$ arborea L.) metapopulation. Conservation Genetics, 7, 825-835.

Berset-Brändli L, Jaquiéry J, Dubey S, Perrin N (2006) A sexspecific marker reveals male heterogamety in European tree frogs. Molecular Biology and Evolution, 23, 1104-1106.

Berset-Brändli L, Jaquiéry J, Perrin N (2007) Recombination is suppressed and variability reduced in a nascent $\mathrm{Y}$ chromosome. Journal of Evolutionary Biology, 20, 1182-1188.
Broquet T, Berset-Brändli L, Emaresi G, Fumagalli L (2007) Buccal swabs allow efficient and reliable microsatellite genotyping in amphibians. Conservation Genetics, 8, 509-511.

Goudet J (1995) FSTAT: a computer program to calculate F-statistics. Journal of Heredity, 86, 485-486.

Goudet J, Raymond M, deMeeus T, Rousset F (1996) Testing differentiation in diploid populations. Genetics, 144, 1933-1940.

Jones KC, Levine KF, Banks JD (2002) Characterization of 11 polymorphic tetranucleotide microsatellites for forensic applications in California elk (Cervus elaphus canadensis). Molecular Ecology Notes, 2, 425-427.

Kimura M, Ohta T (1975) Distribution of allelic frequencies in a finite population under stepwise production of neutral alleles. Proceedings of the National Academy of Sciences, USA, 72, 2761-2764. van Oosterhout C, Hutchinson WF, Wills DPM, Shipley P (2004) MICRO-CHECKER: software for identifying and correcting genotyping errors in microsatellite data. Molecular Ecology Notes, $\mathbf{4}$, 535-538. 